\section{References}

1. Maurizi G, Vanni C, Rendina EA, Ciccone AM, Ibrahim M, Andretti C, et al. Surgery for laryngotracheal stenosis: improved results. J Thorac Cardiovasc Surg. 2021;161:845-52.

2. Liberman M, Mathisen DJ. Tailored cricoplasty: an improved modification for reconstruction in subglottic tracheal stenosis. J Thorac Cardiovasc Surg. 2009; 137:573-8; discussion 578-9.

3. Ciccone AM, Vanni C, Maurizi G, D’Andrilli A, Korasidis S, Ibrahim M, et al. A novel technique for laryngotracheal reconstruction for idiopathic subglottic stenosis. Ann Thorac Surg. 2016;102:e469-71.

4. Hoetzenecker K, Schweiger T, Roesner I, Leonhard M, Marta G, DenkLinnert DM, et al. A modified technique of laryngotracheal reconstruction without the need for prolonged postoperative stenting. J Thorac Cardiovasc Surg. 2016; 152:1008-17.
5. Gelbard A, Anderson C, Berry LD, Amin MR, Benninger MS, Blumin $\mathrm{JH}$, et al. Comparative treatment outcomes for patients with idiopathic subglottic stenosis. JAMA Otolaryngol Head Neck Surg. 2020;146: 20-9.

6. Tanner K, Dromey C, Berardi ML, Mattei LM, Pierce JL, Wisco JJ, et al. Effects of voice-sparing cricotracheal resection on phonation in women. Laryngoscope. 2017; 127:2085-92.

7. Clunie GM, Roe JWG, Alexander C, Sandhu G, McGregor A. Voice and swallowing outcomes following airway reconstruction in adults: a systematic review. Laryngoscope. 2021;131:146-57.

8. Daniero JJ, Ekbom DC, Gelbard A, Akst LM, Hillel AT. Inaugural symposium on advanced surgical techniques in adult airway reconstruction: proceedings of the North American Airway Collaborative (NoAAC). JAMA Otolaryngol Head Neck Surg. 2017;143:609-13.

\title{
Commentary: Inching north up the airway: Thoracic surgeons as complete airway surgeons
}

\author{
Cameron D. Wright, MD
}

Benign subglottic stenosis is most commonly due to prolonged intubation or idiopathic laryngotracheal stenosis. The 2 patient populations are different. Subglottic stenosis due to intubation usually has more involvement of the distal trachea, which can complicate repair because of the length of the involved stenosis, but often spares the subglottic space above the cricoid. Patients with idiopathic stenosis are almost always women with minimal involvement of the trachea, but their disease always extends for a variable amount of distance above the cricoid and can even involve the glottis. Both patient cohorts require resection of both the anterior cricoid and a variable amount of trachea to reconstruct their airway. Whereas a standard cervical trachea

From the Division of Thoracic Surgery, Massachusetts General Hospital, Boston, Mass.

Disclosures: Dr Wright reported consultant for BAYER for chronic thromboembolic pulmonary hypertension.

The Journal policy requires editors and reviewers to disclose conflicts of interest and to decline handling or reviewing manuscripts for which they may have a conflict of interest. The editors and reviewers of this article have no conflicts of interest

Received for publication Dec 4, 2020; revisions received Dec 4, 2020; accepted for publication Dec 5, 2020; available ahead of print Dec 13, 2020.

Address for reprints: Cameron D. Wright, MD, Division of Thoracic Surgery, Massachusetts General Hospital, Austen 7, Boston, MA 02114 (E-mail: cdright@mgh. harvard.edu).

J Thorac Cardiovasc Surg 2021;161:854-5

$0022-5223 / \$ 36.00$

Copyright (c) 2020 by The American Association for Thoracic Surgery

https://doi.org/10.1016/j.jtcvs.2020.12.021

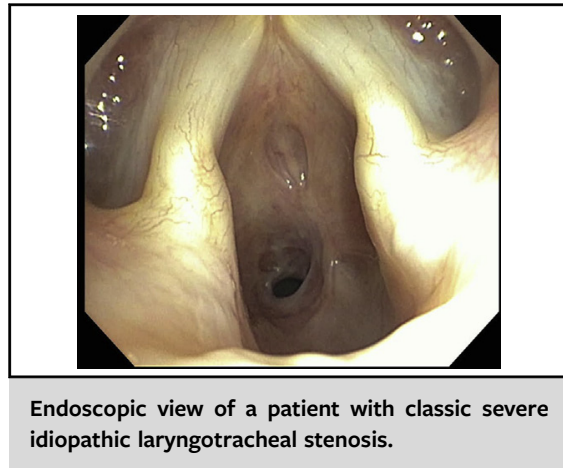

CENTRAL MESSAGE

Laryngotracheal resection for subglottic stenosis in high-

volume centers offers patients a single intervention with excellent long-term results.

resection is a straightforward reproducible operation with excellent results when the larynx is involved, the difficulty is greater and the margin for success is less. The challenges to repair a subglottic stenosis include restoring a reasonable airway in the narrowest portion of the airway (the cricoid), a variable extension of disease above the cricoid into the subglottic space, the proximity of the vocal cords, and the tendency for the vocal cords and immediate subglottic submucosal space to become edematous and thus narrow the airway after operation. The repair of subglottic stenosis is not for the occasional surgeon.

Maurizi and colleagues ${ }^{1}$ report a retrospective series of laryngotracheal (cricotracheal) resections for subglottic stenosis from a high-volume center (average of 30 patients per year over the last 4 years) with excellent results. The early 
success rate was $93 \%$ and the long-term success rate was an astounding $99 \%$. Airway-related complications were low at $8 \%$, which were usually remediated with an endoscopic procedure. In the last 4 years, they were able to shorten the length of stay by 2 days to an average of 7 days. As expected, their strategy and management were altered over time as they gained experience. These improvements include the use of a laryngeal mask airway in some patients, avoiding postoperative short-term intubation, the occasional use of a partial laryngeal fissure when necessary for a very high stenosis, a strategy of favoring immediate resection if one endoscopic treatment fails, and resection of patients with residual inflammation if all inflamed tissue can be resected.

The reported results were rather subjective with a "good voice and breath" and freedom of reintervention. However the long-term bronchoscopic follow-up is remarkable and showed a durable excellent result. Dr Klepetko the Vienna group have set the standard with objective criteria after airway reconstruction with measurements of peak expiratory flow rates and voice quality measurement. ${ }^{2}$
Unfortunately, these measurements are hard to obtain when patients come from a long distance to a major center. Voice quality is not to be discounted, as rigorous studies have documented reduction in the pitch of the speaking voice and the pitch range after laryngotracheal resection. ${ }^{3}$ Most important, however, is the generally excellent results with laryngotracheal resection, which far exceed staged laryngotracheoplasty, which requires postoperative tracheostomy and only $80 \%$ of patients are decannulated. ${ }^{4}$

\section{References}

1. Maurizi G, Vanni C, Rendina EA, Ciccone AM, Ibrahim M, Andreetti C, et al. Surgery for laryngotracheal stenosis: improved results. J Thorac Cardiovasc Surg. 2021;161:845-52.

2. Hoetzenecker K, Schweiger T, Roesner I, Leonhard M, Marta G, DenkLinnert DM, et al. A modified technique of laryngotracheal reconstruction without the need for prolonged postoperative stenting. J Thorac Cardiovasc Surg. 2016; 152:1008-17.

3. Smith ME, Smith ME, Roy N, Stoddard K, Barton M. How does cricotracheal resection affect the female voice? Ann Otolo Rhino Laryngol. 2008; 117:85-9.

4. Ching HH, Mendelsohn AH, Liu IY, Long J, Chhetri D, Berke GS. A comparative study of cricoid tracheal resection and staged laryngoplasty for adult subglottic stenosis. Ann Otolo Rhino Laryngol. 2014;124:326-33. 